\title{
Enyhe szövettani eltérések ellenére gyors progressziójú proliferativ glomerulonephritis monoklonális immunglobulin-G-depozitumokkal
}

\author{
Bajcsi Dóra dr. ${ }^{1}$ - Constantinou Kypros dr. ${ }^{1}$ - Krenács László dr. ${ }^{2}$ \\ Barabás Zsolt dr. ${ }^{3}$. Molnár Szabolcs dr. ${ }^{3}$ - Nyiraty Szabolcs dr. ${ }^{1}$ \\ Ábrahám György dr. ${ }^{1}$ - Iványi Béla dr. ${ }^{4}$ \\ Szegedi Tudományegyetem, Általános Orvostudományi Kar, \\ ${ }^{1}$ I. Belgyógyászati Klinika, Nephrologia-Hypertonia Centrum, \\ ${ }^{2}$ Daganatpatológiai és Molekuláris Diagnosztikai Laboratórium, ${ }^{4}$ Patológiai Intézet, Szeged \\ ${ }^{3}$ Békés Megyei Központi Kórház, Pándy Kálmán Tagkórház, Gyula
}

\begin{abstract}
A proliferativ glomerulonephritis monoklonális immunglobulin-G ( $\operatorname{IgG})$-depozitumokkal entitást immunfluoreszcens vizsgálattal szemcsés mintázatú monoklonális IgG (többnyire IgG3-kappa), elektronmikroszkóppal elektrondenz depozitumok, fénymikroszkóppal jobbára membranoproliferativ vagy endocapillaris proliferativ laesio jellemzi; előfordulhatnak félholdak. A glomerulonephritist plazmasejt/B-sejt klón által szekretált immunglobulinmolekula lerakódása okozza; a biopszia időpontjában csupán a betegek harmadánál mutatható ki paraproteinaemia. A proteinuriához gyakran társul haematuria és valamilyen szintủ veseelégtelenség, a betegek negyedénél alakul ki végstádiumú veseelégtelenség. Egy 62 éves nőbeteg gyors vesefunkció-romlásának hátterében a klinikai kép, a laboratóriumi és a képalkotó vizsgálatok nem támogattak praerenalis és postrenalis okot, illetve intrinsic vascularis vagy tubulointerstitialis eredetet. A proteinuria és a glomerularis microhaematuria alapján gyorsan progrediáló glomerulonephritist valószínúsítettünk. Az ez irányú kivizsgálás antineutrofil citoplazma-antitest, antiglomerularis bazálmembrán, sejtmagellenes ellenanyagok, illetve cryoglobulin tekintetében negatívnak bizonyult, a szérum-C3- és -C4-szint a normális tartományban volt. Vesebiopsziát végeztünk. Immunfluoreszcens vizsgálattal a mesangiumban IgG3-kappa-, C3-és Clq-pozitív szemcsés depozitumok látszottak, melyek ultrastrukturálisan elektrondenz depozitumoknak bizonyultak. Fénymikroszkóppal 2 heges és 29 nyitott glomerulust vizsgáltunk, az utóbbiakban csupán enyhe mesangialis sejtproliferatio mutatkozott. A glomerularis elváltozásokat enyhe arteriola hyalinosis, interstitialis fibrosis és tubulus atrophia kísérte. Proliferativ glomerulonephritis monoklonális IgG-depozitumokkal betegséget kórisméztünk (gyakorisága felnőtt natív vesebiopsziás anyagunkban $0,18 \%$ ). A beteg hematológiai kivizsgálása paraproteint, myeloma multiplexet nem igazolt. Az enyhe morfológiai eltérések ellenére a veseelégtelenség előrehaladt, és a diagnózis felállítása után két héttel hemodialíziskezelést kellett kezdenünk. Szteroid, ciklofoszfamid, majd rituximab adása a vesefunkciót nem befolyásolta; a beteg krónikus hemodialízisprogramba került. Az esetismertetés tudomásunk szerint az első hazai közlés; nefrológiai érdekessége a gyorsan progrediáló glomerulonephritis szindróma és a szövettanilag látott enyhe elváltozások közötti szembetúnő eltérés.
\end{abstract}

Orv Hetil. 2018; 159(38): 1567-1572.

Kulcsszavak: proliferativ glomerulonephritis monoklonális IgG-depozitumokkal, rapidan progrediáló, mesangialis

\section{Rapidly progressive proliferative glomerulonephritis with monoclonal immunoglobulin $\mathrm{G}$ deposits despite the mild histological changes}

\section{Case report}

Proliferative glomerulonephritis with monoclonal immunoglobulin G (IgG) deposits is characterized by granular deposits of monoclonal IgG; histologically it has typically a membranoproliferative or endocapillary pattern, and seen electronmicroscopically there are dense deposits without substructure. Here, we present the case of a 62 -year-old Caucasian woman who was admitted with rapidly progressive kidney failure. The patient's status, the laboratory and 
imaging examinations did not support prerenal, postrenal and - among the intrinsic causes - vascular and tubulointerstitial origin. The proteinuria and dysmorphic microhematuria suggested rapidly progressive glomerulonephritis. Tests for anti-neutrophil cytoplasmic antibodies, anti-glomerular basement membrane, antinuclear antibodies and cryoglobulins were negative, the $\mathrm{C} 3$ and $\mathrm{C} 4$ levels were normal. The biopsy evaluation diagnosed proliferative glomerulonephritis with monoclonal IgG deposits because of mesangial granular deposits of IgG3-kappa, C3, and Clq, and ultrastructurally electron-dense deposits (incidence in our adult native kidney biopsy series: $0.18 \%$ ). 31 glomeruli were assessed histologically. 29 glomeruli displayed mild mesangial hypercellularity, 2 glomeruli were globally sclerotic. Crescents were not observed. Mild arteriolar hyalinosis, interstitial fibrosis and tubular atrophy accompanied the glomerular alterations. In the postbiopsy evaluation, paraprotein or multiple myeloma was not detected. Despite the mild histological findings, the kidney failure progressed, and hemodialysis had to be started two weeks after the biopsy. Steroids, cyclophosphamide and rituximab did not affect her kidney function, and she remained on hemodialysis during the follow-up of 39 months. This report presents for the first time proliferative glomerulonephritis with monoclonal IgG deposits as the possible cause of rapidly progressive nephritic syndrome in the absence of pronounced glomerular proliferative, sclerotic or tubulointerstitial lesions.

Keywords: proliferative glomerulonephritis with monoclonal IgG deposits, rapidly progressive, mesangial

Bajcsi D, Constantinou K, Krenács L, Barabás Zs, Molnár Sz, Nyiraty Sz, Ábrahám Gy, Iványi B. [Rapidly progressive proliferative glomerulonephritis with monoclonal IgG deposits despite the mild histological changes. Case report]. Orv Hetil. 2018; 159(38): 1567-1572.

(Beérkezett: 2018. január 30.; elfogadva: 2018. március 27.)

\section{Rövidítések}

AL-amyloidosis $=($ light - chain amyloidosis $)$ könnyúlánc-amyloidosis; ANCA = antineutrofil citoplazma-antitest; anti-GBM = antiglomerularis bazálmembrán; CRP = C-reaktív protein; eGFR $=$ (estimated glomerular filtration rate) becsült glomerulusfiltrációs ráta; eGFR-EPI = a CKD-EPI (Chronic Kidney Disease Epidemiology Collaboration) kreatininalapú egyenlettel számított GFR; LDH = laktátdehidrogenáz; GN = glomerulonephritis; NSAID $=($ nonsteroidal anti-inflammatory drug) nemszteroid gyulladásgátló; PAS = (periodic acid-Schiff) perjódsav-Schiff; PGNMID = proliferativ glomerulonephritis monoclonalis IgG-depozitumokkal; RAAS = (renin-angiotensin-aldosterone system) renin-angiotenzin-aldoszteron rendszer; RPGN = rapidan progrediáló glomerulonephritis

2004-ben Nasr és mtsai (New York, Amerikai Egyesült Államok) tíz beteg vesebiopsziás eltéréseit és klinikai adatait elemezve új entitásra találtak, melynek a proliferativ glomerulonephritis monoklonális IgG-depozitumokkal (PGNMID) elnevezést adták [1]. A PGNMID a kaukázusi rasszhoz tartozó középkorú és idősebb nókben fordul elő a leggyakrabban, és csupán a betegek harmadánál mutatható ki a keringésben a vesében lerakódott monoklonális immunglobulinnal egyező izotípusú monoklonális immunglobulinmolekula $[2,3]$. A PGNMID klinikailag proteinuriát okoz, melyhez haematuria és veseelégtelenség is gyakran társul [2,3]. A glomeruluskárosodás a betegek mintegy negyedében nem reagál a kezelésre, és 2-3 év alatt végstádiumú veseelégtelenség alakul ki $[2,3]$. Fénymikroszkóppal a gyakoriság csökkenő sorrendjében membranoproliferativ, endocapillaris proliferativ, membranosus, illetve ritkán mesangialis proliferativ GN észlelhetó (1. táblázat) [2, 3]; a membranoproliferativ és az endocapillaris laesio keveredhet egymással $[2,3]$. Félholdak előfordulhatnak $[2,3]$, azonban diffúz félholdas GN csupán elvétve alakul ki [4, 5]. Elektronmikroszkóppal speciális szerkezet nélküli elektrondenz, azaz immunkomplex típusú depozitumok helyezkednek el fóként mesangialisan és subendothelialisan, melyek immunfluoreszcens vizsgálattal szemcsés festődésúek, és a teljes monoklonális IgG-molekulát (a leggyakrabban IgG3-kappa) tartalmazzák [2, 3].

1. táblázat |A PGNMID szövettani jellemzői $[2,3]$

\begin{tabular}{ll}
\hline I. Fénymikroszkópos kép (\%) & \\
\hline Membranoproliferativ & $48-57$ \\
Endocapillaris proliferativ & $26-35$ \\
Membranosus & $5-13$ \\
Mesangialis proliferativ & $3-13$ \\
\hline II. Immunofluoreszcens festések & \\
\hline IgG1-4 szubtípusok (\%) & $24-28$ \\
\hline IgG1 & $6-16$ \\
IgG2 & $60-66$ \\
IgG3 & 0 \\
IgG4 & $70-75$ \\
\hline Könnyúlánc-restrikció (\%) & $25-30$ \\
\hline kappa & \\
lambda & $63-100$ \\
\hline III. A depozitumok elektronmikroszkópos lokalizációja (\%) & $56-95$ \\
\hline Subendothelialis & $17-57$ \\
Mesangialis & $9-14$ \\
Subepithelialis & \\
Intramembranosus & \\
\hline
\end{tabular}

PGNMID = proliferativ glomerulonephritis monoklonális IgG-depozitumokkal 
A monoklonális IgG lerakódása extraglomerularis vagy extrarenalis szervi érintettséget nem okoz, szemben az AL-amyloidosissal vagy a cryoglobulinaemiával. A glomeruluskárosodás kialakulásáról azt gondolják, hogy a B-sejt/plazmasejt klón a jelenlegi módszerekkel kimutathatatlan mennyiségben termel monoklonális IgG-t, mely gyorsan a glomerularis mátrixhoz kötődik, önmagával összecsapzódik, és depozitumot képez $[3,6,7]$. PGNMID-ben a leggyakoribb IgG-altípus az IgG3-molekula. A molekula nephritogen fizikokémiai tulajdonságai az altípus dominanciáját magyarázhatják, ugyanis ez a molekula a leghajlamosabb az önmagával való összecsapzódásra, a legnagyobb a molekulasúlya, a legpozitívabb a töltése, és a legkifejezettebb a komplementkötő képessége [2, 8, 9].

Közleményünkben egy 62 éves nőbeteg kórtörténetét ismertetjük, akinek a kivizsgálása rapidan progrediáló glomerulonephritis (RPGN-) szindróma miatt indult, és a vesebiopsziás vizsgálat PGNMID-t, éspedig annak a legenyhébb, mesangialis proliferatióval járó variánsát találta. A veseelégtelenség terápiarezisztensnek bizonyult, és a beteg a diagnózis felállítása után már röviddel hemodialíziskezelésre szorult. A terápiás erőfeszítések hatástalanok voltak, és a beteg krónikus hemodialízisprogramba került. Az esetismertetés tudomásunk szerint a PGNMID első hazai közlése, nefrológiai különlegessége a gyors és irreverzibilis vesefunkció-romlás és az enyhe szöveti kép közötti ellentmondás.

\section{Esetismertetés}

Klinikánkon az elmúlt 16 évben 551 felnőtt betegnél végeztünk vesebiopsziás vizsgálatot. Monoklonális immunglobulin lerakódása okozta vesebetegség 29 esetben igazolódott: 13 AL-amyloidosis, 4 cylindernephropathia, 5 könnyưláncbetegség, 5 cylindernephropathia és könnyúláncbetegség együtt, 1 cryoglobulinaemiás GN, illetve 1 PGNMID. Az utóbbi a jelen közlemény tárgya.

RPGN-szindróma miatt 2014 októberében egy 62 éves nőbeteg nefrológiai osztályos felvételét kérték. A beteg kórelőzményében 10 éve fennálló 2 -es típusú diabetes, 4 éve fennálló hypertonia és 30 éve fennálló sclerosis multiplex szerepelt, utóbbi specifikus kezelést nem igényelt. Mellkasi panaszok és magas tenzióértékek miatt 2014 szeptemberében kardiológiai osztályos megfigyelés történt, ekkor észlelték veseelégtelenségét: szérumkreatinin-szintje $222 \mu \mathrm{mol} / 1$, a testfelszínre korrigált eGFREPI értéke pedig $22 \mathrm{ml} / \mathrm{min}$ volt. 9 hónappal korábban rutin laboratóriumi ellenőrzés során még $85 \mu \mathrm{mol} / 1$ szérumkreatinin-szintet és $64 \mathrm{ml} / \mathrm{min} / 1,73 \mathrm{~m}^{2}$ eGFREPI-t mértek. A veseelégtelenség dokumentálása előtt a beteg nem szedett potenciálisan vesekárosító gyógyszereket, inzulin mellett évek óta lizinopril-, amlodipin- és metoprololterápiában részesült. Mellkasi panaszainak hátterében akut coronariatörténés, ritmuszavar nem igazolódott, az echokardiográfos vizsgálat balkamra-hypertrophián, kissé tágabb bal szívfélen és nem szignifikáns kombinált vitiumon kívül egyéb eltérést nem írt le. Panaszainak hátterében egyrészt hypertensiv excessus (180200 Hgmm-es systolés vérnyomás), másrészt angina pectoris merült fel, eddigi antihypertensiv terápiája helyett perindopril, indapamid és doxazozin indult, melyet nitráttal, thrombocytaaggregáció-gátlóval és atorvasztatinnal egészítettek ki. Arteria renalis duplex ultrahangvizsgálat normális nagyságú és parenchymavastagságú veséket írt le, szignifikáns arteria renalis stenosis nem igazolódott; a rezisztív index értékei (72-78\%) kisérkárosodásra utaltak, ez azonban gyors vesefunkció-romlását nem magyarázta. A veseelégtelenség dokumentálását követő egy hónapban a beteg szérumkreatinin-értéke $399 \mu \mathrm{mol} / \mathrm{l}$ értékre emelkedett, emellett $1 \mathrm{~g} /$ nap proteinuria (protein-kreatinin hányados: $105 \mathrm{mg} / \mathrm{mmol}$ ) és mikroszkópos glomerularis haematuria is megjelent. Az üledékben dysmorph vörösvértestek és szemcsés cylinderek látszottak. Nefrológiai osztályunkon történt észlelés során a beteg normuriás volt, kétoldali boka- és lábszárödémája, mérsékelt nyugalmi dyspnoéja és magas vérnyomása rendeződött az alkalmazott diéta, valamint a diureticus és kombinált antihypertensiv terápia (telmizartán, lercanidipin, nebivolol, doxazozin) hatására. A szérum méreganyagszintjei azonban tovább emelkedtek, a szérumkreatinin-szint 2 héten belül $602 \mu \mathrm{mol} / \mathrm{l}$-t ért el. Az egyéb laboratóriumi vizsgálati eredmények közül kiemelendők a következók: LDH 574, kontrollálva: $456 \mathrm{U} / 1$, szérumösszfehérje, albumin-, bilirubinszint, thrombocytaszám, CRP-érték normáltartományban, szérumhúgysavszint $523 \mu \mathrm{mol} / \mathrm{l}$. Az izolált, enyhe, gyorsan normalizálódó LDH-emelkedéshez nem társult veseinfarktusra utaló panasz, nem volt a betegnek ezzel kapcsolatos major rizikófaktora, így ezt klinikailag nem tartottuk szignifikánsnak. A hepatitis- és HIV-szerológiai, szérumcryoglobulin-, antistreptolysin-O-vizsgálatok, a szérum- és vizeletelektroforézis immunfixatióval, valamint az autoimmun betegségek irányában végzett szerológiai vizsgálatok (ANCA, anti-GBM, sejtmagellenes antitestek) negatívak voltak, a szérum-C3- és -C4-szint a normális tartományban volt. A csontröntgenvizsgálatok nem mutattak lyticus laesiókat; és nem detektáltunk aktív fertőzésre, vasculitisre vagy malignus betegségre utaló klinikai vagy laboratóriumi eltérést.

A gyors vesefunkció-romlás hátterében - a beteg cardialis statusa, hidráltsági állapota és a vesék ultrahangképe alapján - kizárható volt a prae- és postrenalis eredet. Nem állt fenn olyan etiológiai tényező (például NSAIDterápia, kontrasztanyag adása), mely vas afferens vasoconstrictiót okozhatott volna. Az intrinsic gyors progressziójú veseelégtelenség hátterében felmerülhet vascularis ok, ezek közül a kétoldali arteria renalis stenosist, a vesevéna-thrombosist és a veseinfarktust a renalis duplex ultrahang eredménye és az erre utaló panaszok hiánya nem támogatta; a thromboticus microangiopathiát a laboratóriumi vizsgálatok kizárták, malignus hypertoniára utaló szemfenéki eltérése nem volt. Koleszterinkristály-embolisatióra hajlamosító rizikófaktor nem állt fenn, 

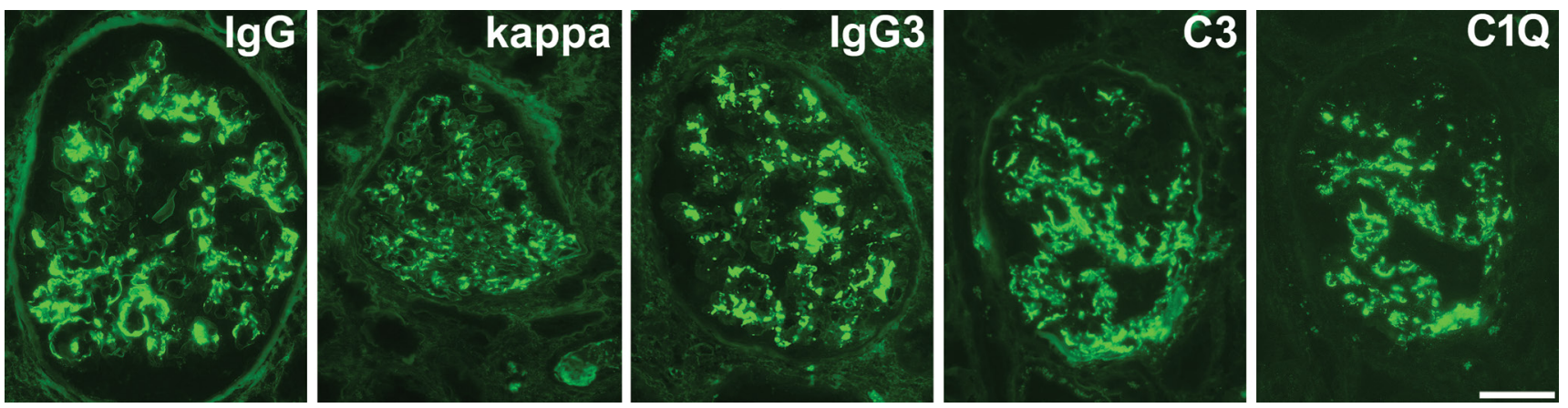

1. ábra

Immunfluoreszcens észleletek. Dominálóan mesangialis IgG-, kappa-, IgG3-, C3- és Clq-depozitumok. Az IgA-, IgM-, lambda-, IgG1-, IgG2- és IgG4-festések - melyek a képen nem láthatók - negatívak voltak. Nagyítás: ×40; lépték: $50 \mu \mathrm{m}$

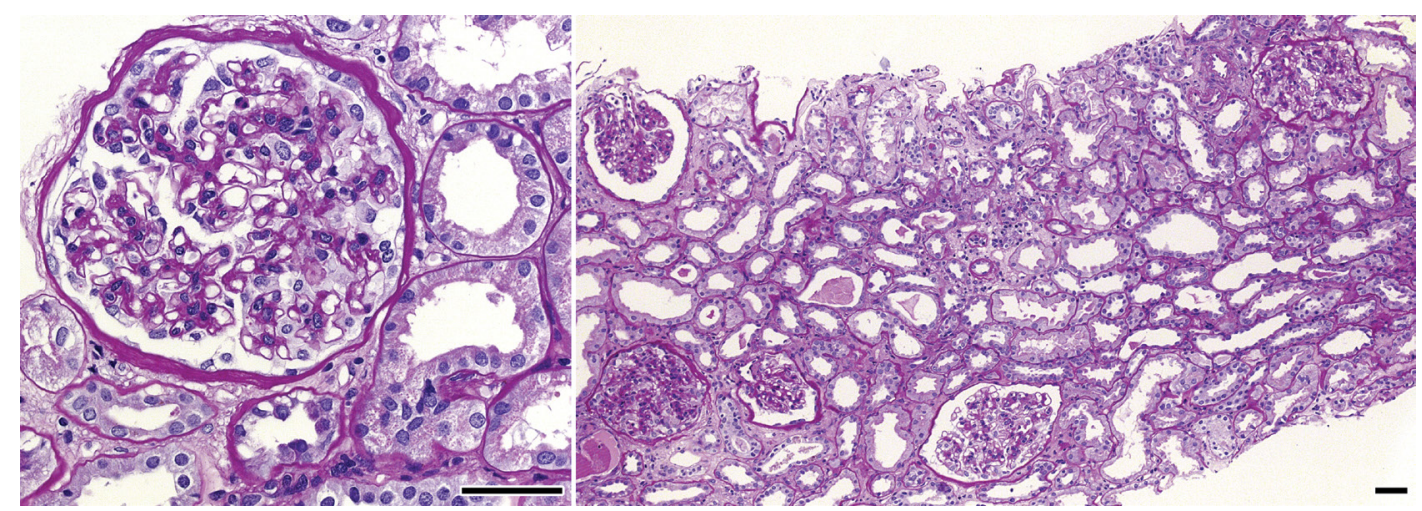

2. ábra

| Fénymikroszkópos észleletek. Bal oldal: enyhe mesangialis sejtproliferatio a glomerulusban (perjódsav-Schiff, nagyítás: ×40; lépték: 50 um); jobb oldal: enyhe proliferativ glomerularis laesio, fokális és enyhe interstitialis fibrosis, tubulus atrophia közepes erősségú nagyításon (perjódsav-Schiff, nagyítás: $\times 10$; lépték: $50 \mu \mathrm{m})$

egyéb szervi érintettség sem társult. A tubulointerstitialis eredet vonatkozásában az akut tubularis necrosis ellen szólt az aktív üledék, a kiváltó etiológiai tényező hiánya és a veseeelégtelenség irreverzibilitása. Akut tubulointerstitialis nephritisszel időnként társuló hiperszenzitivitási reakciót nem észleltünk, a vesék nem voltak nagyobbak, a betegnek nem volt vesetokfeszülésre utaló panasza. A gyors, progresszív vesefunkció-romlás és a glomerularis haematuria alapján elsősorban glomerularis eredet, RPGN merült fel; pontos diagnózist ilyen esetben csak vesebiopszia adhat, így ezt el is végeztük.

A glomerulusok immunfluoreszcens vizsgálata során diffúz-globális, mesangialis szemcsés IgG, kappa, Clq-és C3-festôdés látszott, az IgA, az $\operatorname{IgM}$, a lambda és a fibrinogén festés negatív volt, tehát monoklonális IgG depozíciójáról volt szó. A második körben végzett IgGl-4 szubtípusok értékelése IgG3-restrikciót igazolt (1.ábra). A PAS-festett fagyasztott metszeteken és a formalinban rögzített, paraffinba ágyazott metszetek síkjaiban összesen 2 globálisan heges és 29 nyitott glomerulus helyezkedett el. A nyitott glomerulusokban enyhe mesangialis sejtproliferatiót láttunk; endocapillaris sejtdússág, félhold, valamint szegmentális adhézió sorozatmetszekben sem látszott (2. ábra). A kéregállományi interstitiumban gócosan 20\%-os fibrosis és ezzel arányos tubulus atrophia állt fenn. Az artériák eltérést nem mutattak, az afferens arteriolákban nem körkörös subendothelialis hyalinosis tûnt szembe. A velóállományi interstitiumban gócosan minimális-enyhe fokú lymphocytás beszúrődés látszott néhány eosinophil granulocytával kísérve; tubulitis nem társult hozzá. Az elektronmikroszkópos vizsgálat mesangialisan elektrondenz depozitumokat igazolt (3. ábra). A fenti eltérések alapján PGNMID diagnózisát állítottuk fel; a differenciáldiagnosztikában felmerülő kórképeket (monoklonális IgA-lerakódással járó proliferativ GN, l-es típusú cryoglobulinaemia, fibrilláris GN, valamint immunotactoid GN) kizárták a morfológiai észleletek.

A diagnózis ismeretében plazmasejtes dyscrasia irányában hematológiai kivizsgálásra került sor $[10,11]$ negatív eredménnyel: a szérum- és vizeletimmunfixatióval végzett elektroforézis paraproteint nem detektált; a szérum-szabadkönnyúlánc kvantitatív meghatározása nem igazolt abnormális könnyúláncarányt; a csontvelő biopsziás értékelése a csontvelő cellularitásának kevesebb, mint 10\%-át adó poliklonális plazmasejteket írt le. A komplex vesevédő terápia mellett (a telmizartánkezelést az afferens arteriolákat érintő subendothelialis hyalinosis miatt folytattuk) is tovább romlott a veseelégtelenség, és a vesebiopszia után két héttel hemodialíziskezelést kellett kezdenünk. A szupportív terápia mellett szteroid (metilprednizolon intravénás lökéskezelés, majd per os terápia) és ciklofoszfamid infúziós kezelést alkalmaztunk; azonban a beteg méreganyagszintjei érdemben nem javultak, a beteg oliguriás lett, így krónikus hemo- 


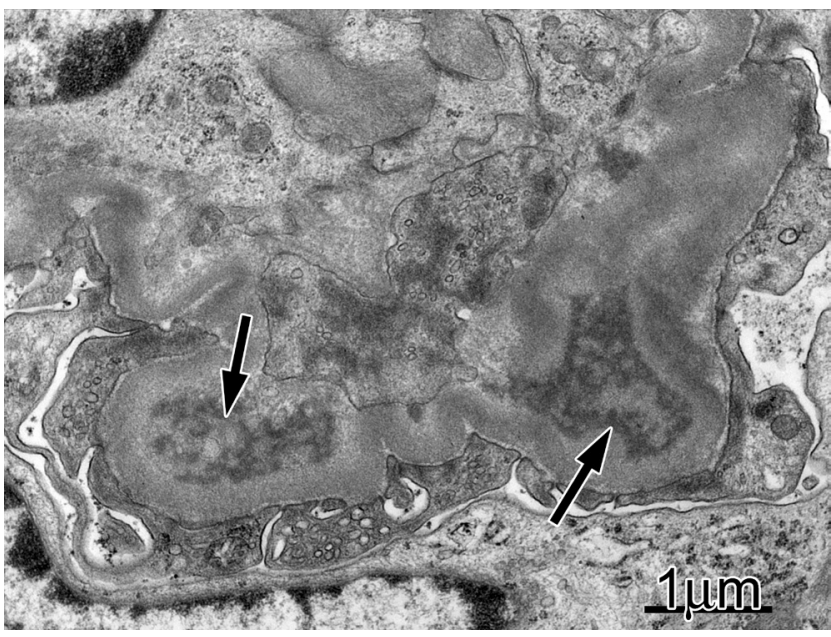

3. ábra

Elektronmikroszkópos észleletek. Elektrondenz, szubstruktúr nélküli depozitumok a mesangiumban (nyíl). Nagyítás: $\times 8000$

dialízisprogramba került. Indikáción túli engedélyezési eljárást követően intravénás rituximabterápiát alkalmaztunk - hetente $375 \mathrm{mg} / \mathrm{m}^{2}$ dózisban négy hétig. A rituximab alkalmazását követően a beteg vizeletmennyisége fokozatosan normuriáig növekedett, de a méreganyagszintek nem csökkentek, így a hemodialíziskezelést nem lehetett felfüggeszteni. A beteg 2018 januárjában továbbra is hemodialíziskezelés alatt áll, vesetranszplantációs várólistán van (az anginagyanú miatt történt coronarographia szignifikáns szúkületet nem igazolt), a veseátültetést követően preventív rituximabterápiát tervezünk - közvetlenül a vese beültetése után.

\section{Megbeszélés}

A PGNMID diagnózisának felállításához a vesebiopszia könnyúláncizotípus-ellenes (kappa, illetve lambda) és IgG-nehézlánc-szubtípus-ellenes (IgG1，IgG2，IgG3, IgG4) antitestekkel történő vizsgálatára van szükség. Magunk a vesebetegségek vizsgálatában a kappa- és a lambda-ellenes antitesteket 1988-tól alkalmazzuk rutinszerűen [12, 13]. Az IgG-nehézlánc-szubtípus-ellenes antitesteket 2014 óta tettük a diagnosztika részévé, döntően a primer és a szekunder membranosus nephropathia elkülönítésére, valamint a monoklonális IgG-lerakódás jellegzetességeinek korszerú elemzésére [14]. A PGNMID ritka betegség. Nasr és mtsai natív vesebiopsziás anyagukban $0,17 \%$-os incidenciát találtak [2]; érdekes módon ezzel szinte egyező, 0,18\%-os gyakoriság adódott a szegedi vesebiopsziás anyagban, tisztán a kaukázusi rasszhoz tartozó populációban.

A 2. táblázat összefoglalja a betegség klinikai jellemzőit két nagy, összesen 91 beteget magában foglaló kohorszvizsgálat adatai alapján [2, 3]. Minden beteg proteinuriás, nephrosisszindróma az érintettek mintegy felében figyelhető meg [2]. A haematuria és a veseelégtelenség szintén jellemző eltérések [2, 3]. A PGNMID klinikai lefolyását a legnagyobb betegszámon Nasr és mtsai vizsgálták; az eredmények változatos, de alapvetöen nem kedvező prognózist igazoltak: a betegek 21,9\%ának veseelégtelensége később végstádiumú veseelégtelenségbe torkollott, komplett remisszió csak 12,5\%-ban jött létre [2]. Többváltozós analízissel a végstádiumú veseelégtelenség kialakulásának egyetlen független prediktora a globális glomerulosclerosis nagyobb százalékos aránya volt [2].

Az RPGN-szindróma ritkán, de előfordul PGNMIDben. Az angol nyelvú irodalomban tudomásunk szerint eddig hat esetet közöltek. Két betegnél az RPGN-szindrómával összhangban diffúz félholdképződést figyeltek meg $[4,5]$, négy betegnél viszont nem látszottak félholdak, a veseelégtelenség mégis 1-3 hónap alatt végstádiumú veseelégtelenségbe torkollott. Az utóbbi betegeknél a scleroticus glomerulusok százalékos aránya 30-62\% között mozgott, és az interstitialis fibrosis és a tubulus atrophia mérsékelt vagy súlyos fokúnak bizonyult [15], vagyis az eltérések nem magyarázták a vesefunkció gyors romlását, a szövettani kép valamilyen mértékben mégis arányban állt a vese funkcionális állapotát jelző klinikai paraméterekkel [15]. Ezzel ellentétben a mi betegünknél csupán a glomerulusok 6\%-a volt scleroticus (ez az érték nem haladta meg az életkorral járó hegesedés mértékét), nem állt fenn félholdképződés, a sejtproliferatio enyhe mértékben csak a mesangiumot vonta magába, és nem tömeszelte el a kacsokat, és az interstitialis fibrosis és a tubulus atrophia a glomeruluskárosodással arányosan enyhe volt. A szövettani kép tehát egyáltalán nem magyarázta a rövid időn belül dialíziskezelést igénylő RPGN-szindrómát, mely a szteroid-, ciklofoszfamid- és rituximabkezelésre is hatástalannak bizonyult.

2. táblázat A PGNMID diagnosztizálásakor észlelt demográfiai paraméterek és klinikai jellemzók $[2,3]$

\begin{tabular}{ll}
\hline Demográfiai paraméterek & \\
\hline Életkor (év) & $55-56$ (20-tól 81-ig) \\
Nem (nő/férfi \%) & $48-62 / 38-52$ \\
Kaukázusi rassz (\%) & $81-98$ \\
\hline Klinikai paraméterek (\%) & 100 \\
\hline Proteinuria & 49 \\
Nephrosisszindróma & 77 \\
Haematuria & 67 \\
Veseelégtelenség & 30 \\
Kimutatható paraproteinaemia & 3 \\
Myeloma multiplex & 11 \\
Szolid tumorok & 3 \\
Autoimmun betegségek & 5 \\
Infekció & $21-27$ \\
Alacsony C3- vagy C4-szint &
\end{tabular}

PGNMID = proliferativ glomerulonephritis monoklonális IgG-depozitumokkal 
PGNMID-ben a különféle terápiás lehetőségek hatékonyságát illetően kevés irodalmi adat áll rendelkezésre. RAAS-gátlók mellett kortikoszteroid-, alkilálóágens-, kalcineurininhibitor-, antimetabolit-, immunmodulátor-, proteaszómainhibitor- és rituximabkezelésekkel történtek terápiás próbálkozások $[1,2,16]$. Guiard és mtsai adatai alapján a hematológiai malignitással nem társuló PGNMID esetén a rituximabkezelésnek van a legkedvezőbb kockázat-haszon aránya [16]. Komatsuda és mtsai közöltek egy szteroidra reagáló, tisztán mesangialis proliferatióval járó PGNMID-esetet [17]. Bár ennek az esetnek a szövettani megjelenése hasonlított az általunk észlelt esethez, sajnos betegünknél a szteroid mellé bevezetett ciklofoszfamid-, majd a rituximabkezelés sem eredményezett javulást a vesefunkcióban.

\section{Következtetés}

Megállapíthatjuk, hogy PGNMID-ben a klinikai kép és a vesebiopszia szövettani eltérései nem minden esetben illeszkednek egymáshoz. Találkozhatunk olyan beteggel, akinél a klinikai kép RPGN-szindrómának felel meg, a vesefunkció gyors romlását viszont a vesebiopsziás eltérések csak részben vagy egyáltalán nem magyarázzák. Ezzel a potenciális diszkordanciával PGNMID diagnózisú betegek esetén mindenképpen tisztában kell lennünk.

Anyagi támogatás: A közlemény megírása anyagi támogatásban nem részesült.

Szerzői munkamegosztás: B. D.: Nefrológus, a beteg kivizsgálását irányította, elvégezte a vesebiopsziát, meghatározta a terápiát, a beteg tercier utánkövetését végezte, és megírta a kéziratot. C. K.: Nefrológus, részt vett a beteg utánkövetésében, és kérvényezte a rituximab indikáción túli engedélyezését a tervezett vesetranszplantációt követően. K. L.: Hematopatológus, a csontvelő szövettani értékelését végezte. B. Zs.: Nefrológus, először észlelte a beteg rapidan progrediáló nephritis szindrómáját, és beutalta vesebiopsziás vizsgálatra. A beteg vesetranszplantációs várólistára kerülése előtti kivizsgálást végezte, emellett aktuálisan részt vesz a beteg krónikus hemodialíziskezelésében. M. Sz.: Nefrológus, a beteg vesetranszplantációs várólistára kerülése előtti kivizsgálást végezte, emellett aktuálisan részt vesz a beteg krónikus hemodialíziskezelésében. Ny. Sz.: Klinikai orvos, részt vett a beteg nefrológiai osztályos ellátásában. Á. Gy.: Az I. Belgyógyászati Klinika igazgatója, a Nephrologia-Hypertonia Centrum vezetője, a terápia szakmai irányítója. I. B.: Nefropatológus, a Patológiai Intézet igazgatója, aki felállította a diagnózist, elkészítette az ábrákat és az ábramagyarázatokat, és ellenőrizte a kéziratot. A cikk végleges változatát valamennyi szerző elolvasta és jóváhagyta.

Érdekeltségek: A szerzőknek nincsenek érdekeltségeik.

\section{Irodalom}

[1] Nasr SH, Markowitz GS, Stokes MB, et al. Proliferative glomerulonephritis with monoclonal IgG deposits: a distinct entity mimicking immune-complex glomerulonephritis. Kidney Int. 2004; 65: 85-96.

[2] Nasr SH, Satoskar A, Markowitz GS, et al. Proliferative glomerulonephritis with monoclonal IgG deposits. J Am Soc Nephrol. 2009; 20: 2055-2064.

[3] Bhutani G, Nasr SH, Said SM, et al. Hematologic characteristics of proliferative glomerulonephritides with nonorganized monoclonal immunoglobulin deposits. Mayo Clin Proc. 2015; 90: 587-596.

[4] Nasr SH, Sethi S, Cornell LD, et al. Proliferative glomerulonephritis with monoclonal IgG deposits recurs in the allograft. Clin J Am Soc Nephrol. 2011; 6: 122-132.

[5] Oshio M, Fujii T, Kusaura T, et al. Relapsing proliferative glomerulonephritis with monoclonal IgG deposits showing circumferential crescentic glomerulonephritis. Clin Kidney J. 2013; 6: 635-638.

[6] Albawardi A, Satoskar A, Von Visger J, et al. Proliferative glomerulonephritis with monoclonal IgG deposits recurs or may develop de novo in kidney allografts. Am J Kidney Dis. 2011; 58: 276-281.

[7] Bridoux F, Leung N, Hutchison CA, et al., on behalf of the International Kidney and Monoclonal Gammopathy Research Group. Diagnosis of monoclonal gammopathy of renal significance. Kidney Int. 2015; 87: 698-711.

[8] Grey HM, Hirst JW, Cohn M. A new mouse immunoglobulin: IgG3. J Exp Med. 1971; 133: 289-304.

[9] Capra JD, Kunkel HG. Aggregation of gamma-G3 proteins: Relevance to the hyperviscosity syndrome. J Clin Invest. 1970; 49: 610-621.

[10] Rajkumar SV, Dimopoulos MA, Palumbo A, et al. International Myeloma Working Group updated criteria for the diagnosis of multiple myeloma. Lancet Oncol. 2014; 15: e538- e548.

[11] Varga G, Mikala G, Váróczy L, et al. Management of multiple myeloma in Hungary in 2016. [A myeloma multiplex megközelítése Magyarországon 2016-ban.] Orv Hetil. 2016; 157: 123-137. [Hungarian]

[12] Iványi B, Nagy J, Varga Gy, et al. Light-chain nephropathy. [A könnyúlánc-nephropathia.] Orv Hetil. 1990; 131: 17911795. [Hungarian]

[13] Iványi B. Frequency of light chain deposition nephropathy relative to renal amyloidosis and Bence Jones cast nephropathy in a necropsy study of patients with myeloma. Arch Pathol Lab Med. 1990; 114: 986-987.

[14] Hemminger J, Nadasdy G, Satoskar A, et al. IgG subclass staining in routine renal biopsy material. Am J Surg Pathol. 2016; 40: 617-626.

[15] Gowda KK, Nada R, Ramachandran R, et al. Proliferative glomerulonephritis with monoclonal immunoglobulin deposition disease: The utility of routine staining with immunoglobulin light chains. Indian J Nephrol. 2015; 25: 344-348.

[16] Guiard E, Karras A, Plaisier E, et al. Patterns of noncryoglobulinemic glomerulonephritis with monoclonal Ig deposits: correlation with IgG subclass and response to rituximab. Clin J Am Soc Nephrol. 2011; 6: 1609-1616.

[17] Komatsuda A, Wakui H, Ohtani H, et al. Steroid-responsive nephrotic syndrome in a patient with proliferative glomerulonephritis with monoclonal IgG deposits with pure mesangial proliferative features. NDT Plus 2010; 3: 357-359.

(Bajcsi Dóra dr., Szeged, Korányi fasor 8-10., 6720 e-mail: bajcsi.dora.ilona@med.u-szeged.hu) 